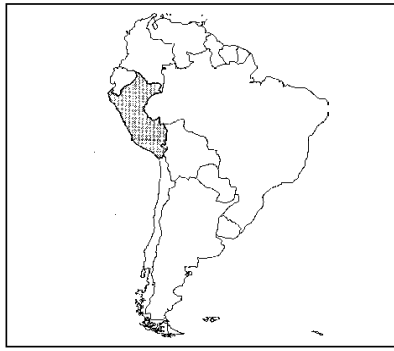

Liliana Miranda is the National Coordinator of the Cities for Life Forum and the Executive Secretariat of the Peru Urban Management Education Programme (PEGUP). Both are located in ECOCIUDAD a Peruvian NGO where she is the vice-president. Trained as an architect, she previously taught urban planning and management at different Peruvian universities. Michaela Hordijk is a geographer specializing in urban environmental management and is external assessor of the Cities for Life Forum. She is currently finalizing a PhD study on the role of local initiatives in urban environmental management in a low income area in Lima, Peru (University of Amsterdam, Department of Human Geography, Centre of Latin American Studies and Documentation, and the Institute for Housing and Urban Development Studies - IHS - in Rotterdam). This paper was prepared with the support of the Swedish International Development Cooperation Agency (Sida) as part of a programme to document innovative Local Agenda 21 processes in urban areas.

Addresses: For Liliana Miranda, Foro Ciudades para la Vida, Ecociudad, Vargas Machuca 408, San Antonio, Miraflores, Lima 18, Peru; e-mail: postmaster@ciudad. org.pe; for Michaela Hordijk, University of Amsterdam, Nieuwe Prinsengracht 130, 1018 VZ Amsterdam, Netherlands, tel. 31-20-5254063, e-mail:mhordijk@knoware.nl.

\section{Let us build cities for life: the national campaign of Local Agenda 21s in Peru}

\section{Liliana Miranda and Michaela Hordijk}

SUMMARY: In March 1996, representatives from several Peruvian cities, grassroots organizations and NGOs, together with scientists and staff from universities and local government authorities, decided to establish a national forum to promote the development and implementation of Agenda 21 in cities in Peru. This came to be called the "Cities for Life" Forum which, today, brings together representatives from 41 institutions in 18 cities. This paper describes the origin and early development of the Forum - and its vision, strategies and work to date. It seeks to show how this Forum developed beyond what was initially a conventional project which depended upon technical assistance and the initiatives of a local NGO into a network of many different actors from many urban centres in Peru who, together, form an autonomous and independent entity. The Forum has encouraged and supported its members in developing and implementing local environmental action plans and in learning from each other's experiences. The paper also outlines the main environmental problems in Peru's urban areas and the unsupportive national framework within which urban authorities and other urban actors strive to address environmental problems.

\section{INTRODUCTION}

THIS PAPER AIMS to share with the reader the spirit of the Cities for Life Forum. We believe that our experience is valuable for two reasons. First, because of the capacity developed by the different local actors (both individuals and institutions) since 1994 whose work has ensured changes and improvements in our cities, and second, because it shows how we learn from our own experience and construct theories, concepts, methodologies and instruments that are suited to our problems and thus to concrete possibilities for action.

We want Cities for Life to be for Peruvians - rooted in the knowledge and culture of Peruvians. This paper is an affirmation of Peruvian knowledge, of learning from experience and of the capacity, both individual and institutional, of our communities, technicians, authorities, business people and institutions. Box 1 outlines the shared vision of the Forum, a vision which is the result of joint efforts by all the Forum members. In fact, most of 
Map 1: Cities in Peru where there are Members of the Forum

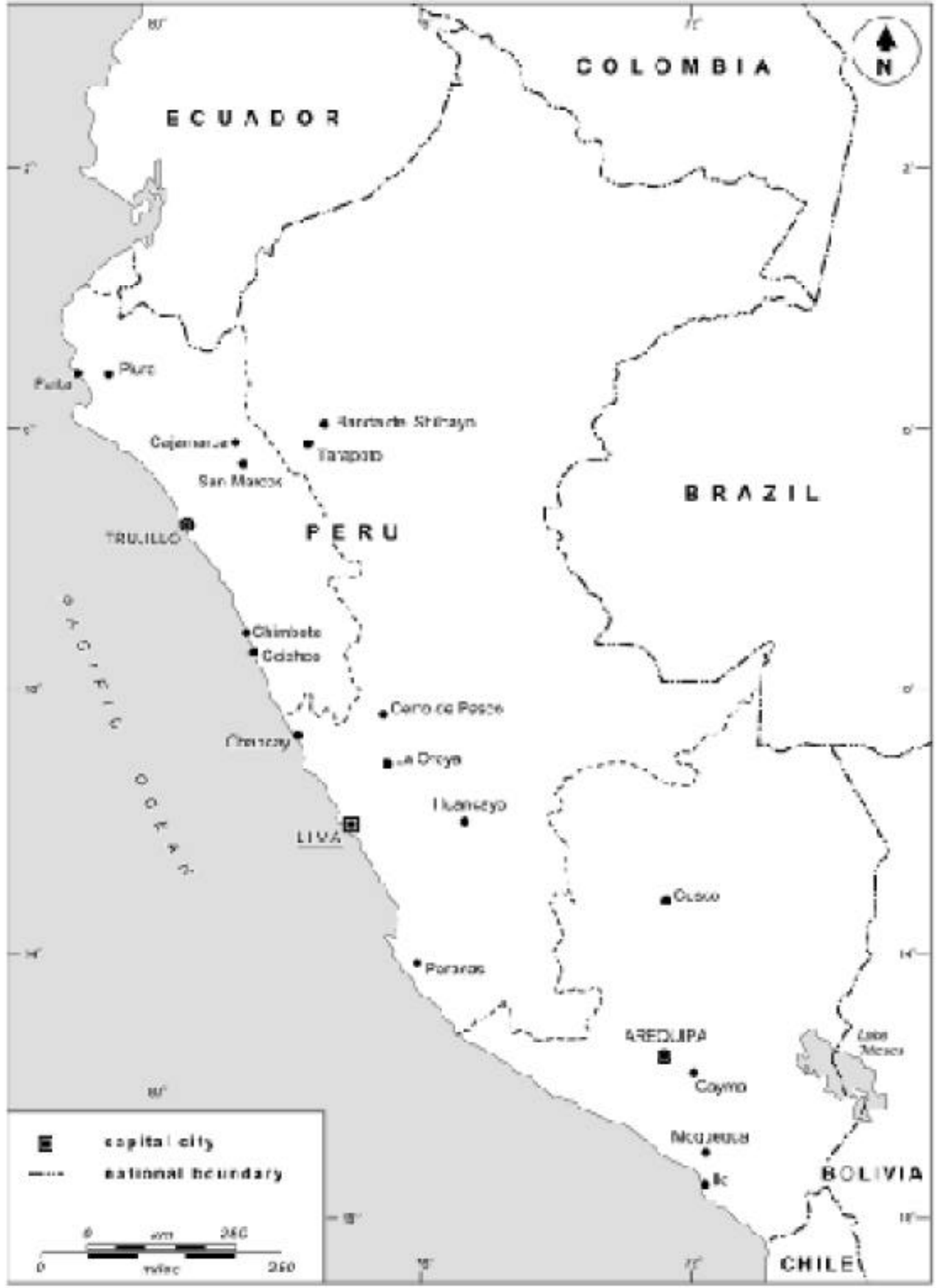


the contents of this paper - the working methodology developed, the mission, the strategy and objectives, and the activities described - are the result of joint action and reflection by Forum members, although the opinions expressed are those of the authors.

\section{Box 1: Our Vision \\ We want "cities for life" that are an expression of sustain- able development, which offer their inhabitants an ad- equate quality of life and equitable opportunities for healthy, safe and productive lives that are rooted in soli- darity. Such "cities for life" should also be in harmony with nature and the rural surrounds, cultural traditions and spiritual values, and adapted to the diversity of our country.}

We want "cities for life", whose inhabitants identify themselves with their city's development, who are proud of their culture and the natural beauty of the place where they live, who work collaboratively, are competitive but also practise solidarity.

We are convinced that it is a mistake to develop a single proposal for national development without taking into consideration local characteristics, resources, capacities or political will. To be viable and implementable, national development has to be linked to local development. The experience and, especially, the reality of Peru today are in need of a policy of this kind.

The strategic problem of our cities is one of management. Effective management requires both individual and institutional actors capable of leading and sustaining it. It requires the bringing together and harmonization of different sectoral actions and institutions. It has to be built on the lessons of experience that help give us practical models and replicable operations. The proposals and recommendations within international agreements, such as Agenda 21 coming out of the UN Earth Summit in Rio de Janeiro in 1992 and the Habitat Agenda coming out of the UN City Summit in Istanbul in 1996, can be valuable instruments if we know how to adapt them to our national and local realities and contexts. Local Agenda 21s are valid where they have been interpreted as concrete and operative action

1. The concept of concertación is difficult to translate. It goes beyond consultation and brings the different stakeholders around the table so that solutions can be negotiated and responsibilities assigned. This includes conflicting interests, where these exist. plans, formulated with leaders who practise concertación, ${ }^{(1)}$ who realize concrete actions which address the problems of the poorest and contribute to local urban sustainable development in Peru.

Thus, environmental management within Peruvian cities must look at the short and long term to be effective and must overcome the electoral instability of the authorities in order to construct a shared vision of the future that incorporates an environmental focus in all its actions. It must develop concerted processes which are truly democratic, decentralized and participatory. These processes must institutionalize an integrated system of local environmental management which organizes the 
course of action and promotes the mobilization of local resources that can ensure a continuous process of urban investment, as an essential component of the Local Agenda 21.

The Cities for Life Forum is without precedent in Peru. It consists of 41 institutions (municipalities, NGOs, grassroots organizations, universities) from 18 different Peruvian cities - see Box 2 . It constitutes an institutional framework for supporting the development of management capacities. It is also a concrete example of bringing different actors to work together in capacity-building and the formation of leaders committed to achieving cities for life.

\section{Box 2: Members of the Cities for Life Forum}

Municipalities: Banda del Shilcayo, Cajamarca, CaymaArequipa, Cerro de Pasco, Chancay, Huancayo, Ilo, La Oroya-Yauli, Nuevo Chimbote, Moquegua-Mariscal-Nieto, Paita, Paracas, Piura, San Marcos-Cajamarca, Tarapoto and Trujillo (all of which are secondary cities), plus the Municipality of Metropolitan Lima.

Civil Society: ADECOMAPS (Asociación para el Desarrollo y Conservación del Medio Ambiente de la Provincia del Santa), Bartolome de las Casas (Centro de Estudios Regionales Andinos), Calandria (Asociación de Comunicadores Sociales), CENCA (Instituto de Desarrollo Urbano), CIDAP (Centro de Investigación, Documentación y Asesoria Poblacional), DESCO (Centro de Estudios y Promoción del Desarrollo), Ecociudad, Comunidad Urbana Autogestionaria de Huaycán, Cooperaccion (Accion Solidaria para el Desarrollo), IDEAS (Centro de Investigación, Documentación, Educación, Asesoria y Servicios), INDES (Instituto Nor Peruano de Desarrollo Económico Social), IRESIMA (Instituto Regional Salud Integral y Medio Ambiente), IPES (Instituto de Promocion de la Economia Social), IPEMIN (Instituto de Pesca y Mineria), FOVIDA (Fomento de la Vida), Fundación Maria Elena Moyano, LABOR/Ilo (Asociación para el Desarrollo), LABOR/Pasco (Asociación para el Desarrollo), NATURA (Instituto Ecológico) and OACA (Oficina de Asesoria y Consultoria Ambiental).

Universities: UNI (Universidad Nacional de Ingeneria)/ Masters School for Architecture, Urbanism and the Arts (FAUA) in Lima; UNSA (Universidad Nacional de San Agustin)/Postgraduate programme of Architecture and Urbanism (FAU) in Arequipa; and UPAO (Universidad Privada Antenor Orrego)/Faculty of Architecture and Urbanism (FAU) in Trujillo.

Thus, this paper seeks to share the lessons we have drawn from experience, from the practice of negotiation, from the wideranging exchange of information, from the self-development of empowerment and from our permanent efforts and capacity for dissemination. 


\section{THE URBAN ENVIRONMENTAL REALITY OF PERU}

THROUGHOUT PERU'S LONG colonial and republican history, the state and civil society placed very little importance on environmental issues. The Inca and pre-Inca knowledge of sustainable management of the land and its harmonious relation with nature have been forgotten or undervalued for hundreds of years. This absence of political will within government to address environmental problems remains one of the most serious problems and also one that is difficult to turn around.

One example of this lack of political will can be seen in a meeting in Arequipa in 1996 which brought together top and medium-level business people from all over Peru. President Alberto Fujimori told the press that the main national priority was economic development and pacification, expressly relegating environmental concerns to a secondary concern. A reinsertion of the Peruvian economy within the world economy, financial stability, growth in Peru's gross domestic product, fiscal austerity, more foreign investment and poverty reduction were the priorities of national policy. ${ }^{(2)}$ The president's absence from both the first and the second Eco-dialogue, in 1996 and 1997, organized by the National Environmental Council ${ }^{(3)}$ in Ica is another example of the national government's lack of interest in environmental issues.

One strength of our country is that it is characterized by a strong culture of solidarity, mutual aid and people's capacity to work together, particularly at a local level. In part, this comes from the Andean tradition. Fortunately, these values are now also part of the life of the population, especially the urban population. It can be identified in the illegal or informal settlements in urban areas, where the population must work together in order to improve their living conditions, and amongst poor municipalities which depend on such a strategy to achieve results.

Peru experienced one of the most interesting decentralizing initiatives in the 1980s. In that decade, power, responsibilities and financial resources were transferred to the municipalities (see Box 3). It was the decade in which a new municipal law, la ley organica de municipalidades, was adopted and, for the first time, municipal responsibilities, functions and powers were laid down in a coherent framework. This included responsibilities and functions relating to environmental issues such as water and sanitation, garbage collection and the management of public space. Unfortunately, the responsibilities and functions of other authorities were not equally curtailed, so the legal framework gives rise to many conflicts over who is responsible for different tasks. But a local government that knows how to work within this law can still operate with a lot of autonomy.

In spite of the leadership of President Alberto Fujimori from 1990, during which an accelerated process of "recentralization" was introduced, municipal autonomy persists especially outside the national capital, Lima. This allows mayors with the capacity to develop and implement proposals to lead in the promotion of local sustainable development. 
4. Instituto Nacional de Estadisticas y Informaciones (INEI) Proyecciones as año 2010, Lima.

5. Censo Nacional de Población y Vivienda (1993), INEI, Lima.

6. According to the IIEP (1996), other funds transferred for specific uses (e.g. "Glass of Milk") have been raised to 8 per cent.
Box 3: The Decentralization of Responsibilities to the Municipal Level

In the Ley organico de municipalidades the following issues were delegated to the competence of the municipal authorities:

- planning of roads, urban transport and traffic management (including, for instance, organizing and maintaining traffic lights);

- planning of basic social services (health and education) for kindergartens and primary schools; campaigns for literacy; and primary health care centres;

- planning and remodelling the squatter settlements, providing technical support in the process of legalization of the squatter settlements;

- expropriation of private land that had been invaded;

- giving out land titles;

- licensing of buildings and of commercial activities;

- control of markets and street vendors;

- protecting and promoting parks, squares and monuments and, more broadly, protecting cultural heritage;

- promoting cultural activities and sport and recreation.

\section{ENVIRONMENTAL PROBLEMS IN PERUVIAN CITIES}

PERU IS A predominantly urban country. Close to three-quarters of its population already live in urban areas and projections suggest that nine out of ten Peruvians will soon live in urban areas. ${ }^{(4)}$ Most of our population is poor. Four million families live in poverty and, of these, 2.5 million live in "extreme poverty", mostly in urban areas. ${ }^{(5)}$ Urban authorities can be said to suffer from institutional poverty; the 2,000 local governments in Peru receive only 4 per cent of the national budget from central government. ${ }^{(6)}$ The vast majority of the state's resources are earmarked for repayments of the national debt or for military expenses. If social investment has increased in recent years, it continues to be far below what is needed - and virtually all of it is managed by the Ministry of the Presidency.

Figures from the 1993 census show that, at the time, 67.7 per cent of the population was concentrated in 462 urban centres. The high level of government centralization in Peru is reflected in the fact that the national capital, Lima, with 6.7 million inhabitants in 1993 accommodated 43.8 per cent of the urban population. This was also one-third of the total population. The data also show that eight further cities had populations of between 250,000-1 million (representing 20.2 per cent of the urban population) and 21 cities between 50,000-250,000 inhabitants (representing 14.4 per cent of the urban population). Thus, 34.6 per cent of the urban population of the country is found in the 29 largest cities after Lima, which, together, still have a 
smaller combined population than Lima. Centralism continues to be one of the main structural problems that inhibits development possibilities for all localities.

The vast majority of the 29 cities suffer from severe deficiencies in their basic infrastructure - for instance in the provision of safe and sufficient piped water supplies, and of sanitation and drainage. In many, industrial and mining activities generate dangerous levels of air pollution while their wastes cause serious land and water pollution, endangering human life and damaging ecosystems. For instance, the entire population of Cerro de Pasco showed signs of lead residues in their lungs due to the activity of a mining company owned by the Peruvian government. In Ilo, the second highest cause of death is lung cancer and this is linked to the high levels of pollution coming from the copper refinery of the Southern Copper Corporation of Peru. In Chimbote, average life expectancy is ten years lower than the national average and premature death among the population is linked to high levels of pollution caused by the steel plant owned by the government, and to the operations of canneries and fishmeal producers. All of these cities are members of the Forum.

In its National Agenda on Environmental Action, the National Environmental Council (CONAM) has stated that poverty is the principal environmental problem in Peru. This can be understood in two ways. First, poverty and environmental risks go together in most cities. The poor are more exposed to the most common urban environmental problems such as the diseases linked to the inadequate provision of urban services, air and noise pollution, contaminated food and a lack of access to natural resources and green areas. They are generally more vulnerable to disasters as they have no alternative but to live on land sites that are more at risk from floods, landslides or other hazards. They also suffer directly from the absence of appropriate urban planning and management systems. This has obvious impacts on their quality of life since it affects their health and reduces their productivity and their economic capacity. It also brings a serious deterioration in the historical and the natural heritage of neighbourhoods and cities.

Secondly, poverty, more than any other factor, inhibits the possibility of improving environmental conditions. To confront both problems requires integrated, long-term strategies but these problems should be recognized as the symptoms of certain underlying structural causes:

- The inability of technicians and authorities, as much at local as at national level, to recognize and manage imbalances generated by the concentration of population in the cities.

- Insufficient supply of housing and urban services, especially in relation to the rapid population growth.

- A short-term view by national government, local authorities and the population which may resolve some current problems but without taking the action that would prevent or greatly reduce problems in the future. 


\section{See reference 4 .}

8. Dr. Mariano Castro, CONAM, in a presentation at the first course for environmental promoters for cities, Arequipa, May 1997.

9. See reference 8 .
- Allowing the cities to concentrate industrial, mining and other economic activities which can maximize profits without taking action to control the high environmental costs they generate for the population or ensuring the long-term sustainability of their activities or their use of natural resources.

- Urban land markets which remain speculative and exclusionary.

- The double tendency of spatial concentration and specialization of land use which leads to "over-exploitation" of certain areas in cities. This causes high pollution levels and social problems in particular districts. Enterprises are concentrating because of economies of scale, within cities whose authorities fail to control pollution.

- The weakness of local institutions, both governmental and within civil society. This is particularly the case for local government which lacks not only resources but also the capacity to make good use of the resources that do exist. One factor in this is the lack of specialized professionals trained in environmental management.

- The lack of political will to face environmental problems, whether due to ignorance of the subject or to vested interests.

\section{IV.TRENDS}

UNLESS ACTION IS taken, urban environmental deterioration is set to rise since projections suggest that, by the year 2010 , Peru will have 30 million people living in 21 cities of more than 100,000 inhabitants. ${ }^{(7)}$ The low coverage and poor quality of the principal urban services (water, sanitation, collection and disposal of garbage, provision and maintenance of green areas and other public spaces) will continue and industrial pollution will rise until immediate corrective action is taken. ${ }^{\left({ }^{(8)}\right.}$

For the country as a whole, environmental deterioration has become a permanent feature. For instance, large areas of irrigated land are no longer productive and soil erosion affects large areas; 60 per cent of coastal lands are suffering from accelerated erosion while 42 per cent of the Amazon territories are suffering from light to serious erosion. Some 5 million hectares of forest have been destroyed in recent years and current estimates suggest that a further 380,000 hectares are being lost each year - which is equivalent to an area the size of a football field, each minute. ${ }^{(9)}$

Peru's economy and society depend on its ecology, especially on a diversified agriculture, hydro-electricity, mines and tourism - and with the latter dependent on Peru's rich ecological and cultural heritage remainaing intact. This rich ecological heritage can be seen in the fact that Peru is considered one of 
10. The other countries are Colombia, Mexico, Brazil, Madagascar, Australia and the Congo (formerly Zaire).

11. See reference 8 .

12. CONAM, Política Ambiental Peruana (Peruvian Environmental Policy), Lima. the seven countries exhibiting "mega-biodiversity" due to the exceptional range of local ecosystems. ${ }^{(10)}$

\section{THE INSTITUTIONAL NATIONAL FRAMEWORK}

\section{a. Negotiation as an Option}

PERU HAS A legislative framework for environmental protection and management that is contradictory and inconsistent. CONAM, the highest environmental authority in the country, states that there are over 7,000 environmental norms that have been approved since 1904 that remain in force. ${ }^{(1)}$ Many either contradict or replicate each other. This contributes to a spread of responsibility (and lack of coordination), institutional weakness, centralization and sectoral approaches when inter-sectoral approaches are needed. To this are added a lack of capacity for coordination, integration and supervision, as well as a lack of effective mechanisms for citizen participation.

Positive changes are hoped for since, recently, Congress announced the revoking of thousands of these laws to re-order the legislative framework. Meanwhile, CONAM is completing a study for the establishment of the National Environment System. This includes a recognition of the need to establish intersectoral processes which help develop both market and political capacities, and instruments that are participatory and transparent.

The different bodies within central government and its decentralized agencies have the most important role in the development of policy and environmental management under the coordination of CONAM (which was created in 1994). However, to date, the process of untangling and reforming the legislative base has hardly begun.

Thus, as with many other issues, environmental issues are neither integrated nor coordinated within the government bodies. Concertation on environmental issues is even further away. The spread of authority and of responsibility for environmental management between a series of public bodies has brought many problems of lack of coordination and communication. It has also contributed to a large number of judicial conflicts which the contradictory laws helped cause.

The National Environmental Code, approved by law in 1994, entrusted CONAM with the mission to "...promote sustainable development which brings a balance between socio-economic development, use of natural resources and the preservation of the environment." ${ }^{(12)}$ The Director and Executive Secretary were installed in 1995 and report to the President of the Council of Ministers. This agency's responsibilities is cross-sectoral however, the results of its work will not be seen for some years to come.

CONAM is also meant to coordinate the policies of all the other institutions with some responsibility for urban environmental issues - for instance, each Ministry has an environmental 


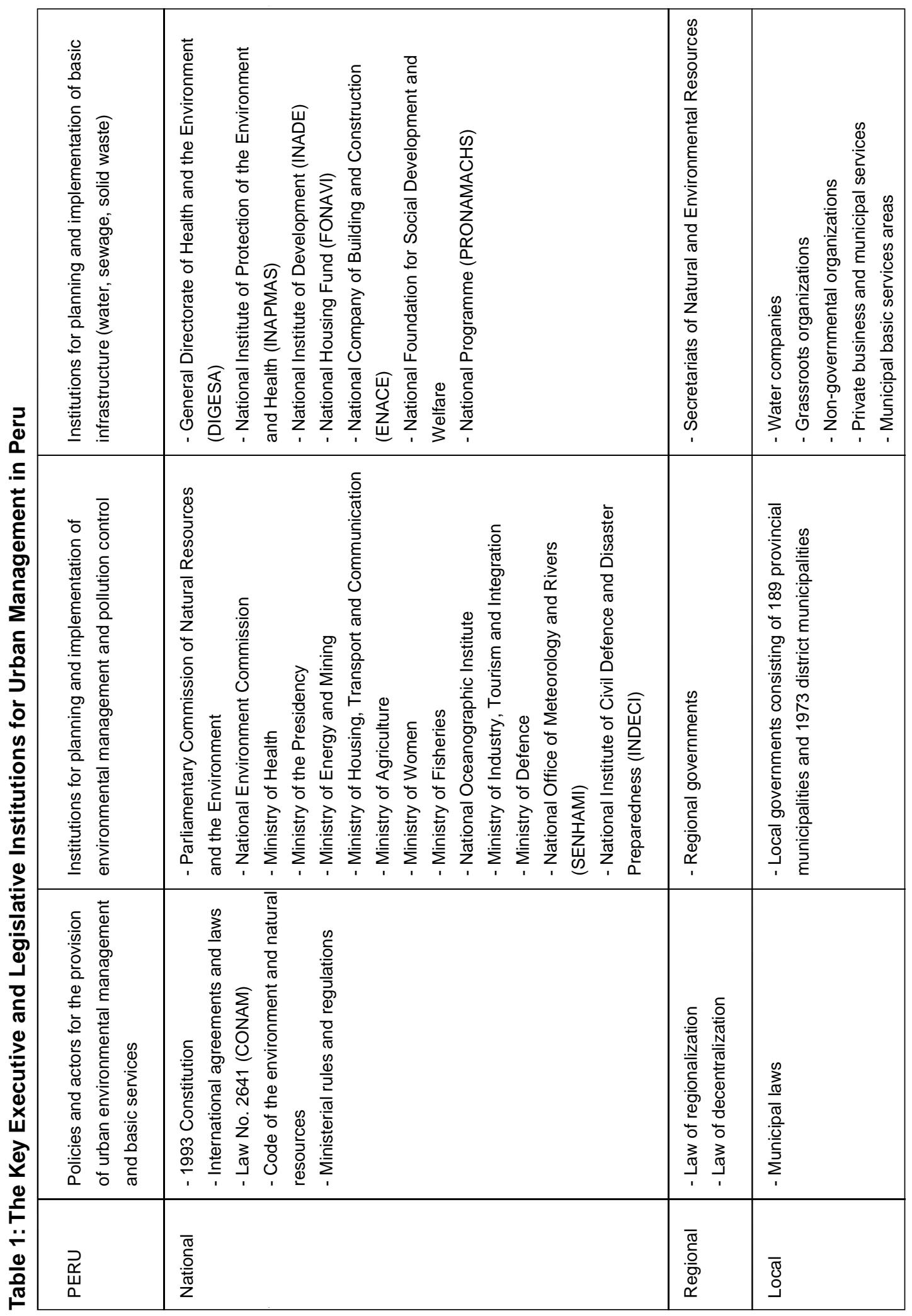


13. Irigoyen, M. (1996), "Concertación interinstitucional y mejoramiento ambiental en San Marcos-Cajamarca" in Ciudades para la Vida, experiencias exitosas y propuestas para la Acción, Lima. office, all of which are meant to coordinate their policies through CONAM. Table 1 outlines the many different institutions with responsibilities in this area. ${ }^{(13)}$

In addition, there is a series of local organizations working on urban environmental issues, generally set up by municipal authorities. The municipalities have developed the functions and responsibilities of environmental management using the Law of Municipalities, within which these responsibilities fall principally upon local governments. Despite the limitations and confusions within the law, these have permitted or facilitated some processes or actions for environmental protection and conservation. One example can be found in San Marcos-Cajamarca see Box 4.

Box 4: Inter-institutional Consultation in San Marcos

San Marcos-Cajamarca, in the northern Andes of Peru, was one of the regions hardest hit by the cholera epidemic in 1993. The provincial government and seven district municipalities and public and private organizations joined forces in an effort to improve sanitary infrastructure. Without relying on predetermined, formally approved plans or budgets, they established an agreement and a coordinated action plan and investment programme. The results of this approach - bringing together funds and coordinating investments and interventions - was so successful that they continued working together when the cholera epidemic was over. Their joint investments in sanitation and awareness-raising developed into a wider programme which included land management and waste disposal. This process of negotiation and joint action through the body they formed - CINDESAM (the Inter-institutional Consultation and Urban Environmental Management in San Marcos) - is not formalized by any specific norm or rule but is perfectly legal in the sense that the existing legislation does not prohibit such an approach. Today, it is the most influential institutional space in the province. In a country as highly politicized as Peru, it is quite an achievement that mayors from different political parties, departments of national government, local NGOs and international donors manage to work together. One of the key lessons, according to the mayor of San Marcos, is that they only work together on issues they can agree upon. In other words, all those issues where conflicting opinions or interests exist are accepted but these conflicts are not allowed to inhibit joint action where agreements can be reached.

San Marcos-CINDESAM serves as an example of the effective use of (legal) autonomy of local municipalities and other actors, that also builds on the potential of the population and other actors. 
Thus, a contradictory national framework and the absence of political will within central government to address environmental problems do not stop local governments, institutions and populations coming to agreements and forming successful environmental action plans in their cities. The most important factors in developing such action plans are the perseverance and capacity of local institutions, leaders, community representatives, professionals and local authorities to negotiate agreements. No central or regional government and no company has had the capacity to contradict or ignore actions which develop from negotiations of this kind - at least in the long term.

This level of agreement is generally achieved when the population understands the environmental problems, is aware of the risks from high pollution levels and sees the consequences of the problems within their families; also, when they see that they can take action, and work with local government and make use of local resources. Local leaders emerge and develop their leadership qualities as the serious health impacts of pollution become evident over a number of years. They become a powerful instrument for change and for the promotion of local sustainable development.

Thus, despite the many problems and the contradictory and unsupportive legislative base, opportunities and strengths also exist. Cities are not only centres of pollution but also sources of local economic development and innovation.

\section{HOW THE CITIES FOR LIFE FORUM DEVELOPED}

THE PROCESS BY which the Cities for Life Forum was constituted and consolidated was never a theoretical exercise. The principal strategy was, and remains, to develop the capacities of leaders, citizens, authorities and institutions, supporting those who are already active in resolving problems in their own cities.

This began as a traditional project. During preparations for Habitat II (the second UN Conference on Human Settlements in Istanbul in 1996), the Dutch government decided to fund an international exchange project. Its objective was to compare and analyze best practices in urban environmental management in three countries, namely India, Peru and Bolivia, and to disseminate the findings. The project was coordinated by the Institute for Housing and Urban Development Studies (IHS) in Rotterdam. In Peru, the work was coordinated by the Institute for Local Development (IPADEL), a Peruvian NGO specializing in local government development, whose function was to supervize the research projects, make an analysis of best practices and organize meetings and seminars relevant to the project. IHS provided some technical assistance.

From the outset, the project in Peru took on its own dynamic. The coordinating team, in consultation with IHS, decided to develop its own strategy which included obtaining more information and involving more people and institutions than had originally been envisaged. What was initially conceived as a project 
for designing training strategies for capacity-building was transformed into an exercise in the development of capacities where we Peruvians learnt from ourselves.

The project began with a seminar bringing together a large number of people and institutions who worked together to develop terms of reference for the national competition "Best Practices in Urban Environmental Management”. Here, the process of learning began to take shape as, at the time, urban environmental management was a new topic in Peru. Although many Peruvian institutions already had significant experience in environment related issues, they did not consider that they were working in urban environmental management. The project's coordinating team had to make several field trips to "awaken" the capacities of people working on this theme and to develop a basic inventory of available experts and experience. In effect, this first seminar brought together people and institutions who were working in urban environmental management even if many of them did not realize they were doing so. It was also the first attempt at a collaborative effort to incorporate Local Agenda $21 \mathrm{~s}$ into existing initiatives in Peru, although many of the participants were not familiar with the concept of Local Agenda 21s.

From the outset, urban planning was linked with environmental planning. This produced much discussion and gave rise to certain conceptual and practical disagreements. At the root of these disagreements were conflicts of interest. The conventional urban planners and members of the "old guard" institutions usually have common links. Today, their work is threatened by constant budget cuts and they feel threatened by the appearance of various environmental institutions who work with the interests and demands of foreign donors who, in turn, are becoming increasingly sensitive to environmental issues. The seminar provided the opportunity for these different groups to convince us that if efforts were united, we could all benefit. But it also made clear that united efforts required substantial efforts at negotiation.

It was from this first seminar that an informal network began. The seminar also produced the terms of reference for the first competition for Best Practice in Urban Environmental Management. An independent jury selected the five best practices which became eligible for a prize that funded a scientific analysis of their experiences. This research should identify the key factors underpinning the best practices and indicate the conditions necessary for supporting comparable practices in other locations.

From the five "best practice" cases selected, three were innovative practices in integrated environmental management:

- The protection of the Pantanos de Villa, which was one of the last green areas in Lima after decades of rapid urban expansion. This was implemented by different government and nongovernment actors who worked together to protect the marshland, each having their responsibilities. Within a few years, Pantanos de Villa had been converted into an attractive park with visitors, provision for exhibitions and resources for scientific and other work. 
14. For more information, see Balvín Díaz José, Doris, Follegatti, Luis López and Michaela Hordijk (1996), "Innovative urban environmental management in Ilo, Peru" in Environment and Urbanization Vol.8, No.1.
15. The studies and several other articles are published in Spanish by the Urban Management Programme's Office for Latin America and the Caribbean in Quito (1996), Ciudades para la Vida, experiencias exitosas y propuestas para la acción, Serie Gestión Urbana No.6, Lima, available from Ecociudad. English versions published as working papers are available from IHS (Rotterdam).
- Environmental management in the city of Ilo in southern Peru - which owed much to the efforts of the charismatic leaders of the local governments. NGOs, community based organizations, public utilities and, to some extent, the private sector were brought together around "a positive vision of the future of Ilo". This participatory development of a "shared vision of the future" was implemented through an incremental approach, starting with small-scale pilot projects that proved the viability of the approach. ${ }^{(14)}$

- Inter-institutional coordination and environmental improvement in San Marcos-Cajamarca in response to the cholera epidemic. Here, a team led by the provincial government was formed to ensure coordinated action. This began with just a few actors working in water supply and hygiene but developed into an organization which brings together the governments of the province and six districts, national government entities, local NGOs, multilateral donors and some grassroots organizations. It works in many different areas, including research (for more details, see Box 3).

The other two "best practices" selected by the jury were more sectoral:

- Micro-enterprises for the collection of solid waste in Lima. A local NGO helped the inhabitants in low-income neighbourhoods of Lima to establish micro-enterprises to collect solid wastes, clean streets and maintain green areas. The study judged the specific conditions of waste collection - which used a low-cost technology - to be viable as an alternative to conventional waste management practices. Over 100 small-scale enterprises were set up, most of them with around eight members, the vast majority of whom were women. Not all of the micro-enterprises survived. The case study also identified which institutional framework offered favourable conditions for the micro-enterprises.

- Rotating credit funds for sanitation and water. A local NGO provided training and credit for the construction of water tanks and latrines in poor districts in southern Lima. The people organized themselves and sought help to implement their projects. A micro-business was formed to take care of the construction of the tanks and latrines. Over 12,000 people were trained in water management and hygiene and 1,187 families received credits for sanitary infrastructure. The study included a careful analysis of the increase in the costs of managing such rotating funds. ${ }^{(15)}$

Each of these best practices was analyzed by its own main actors. This meant that careful monitoring of the analysis was required, to avoid focusing on only one point of view. Instead of turning this process into something scientific and academic, we had the option of creating a public event, open to all interested people, seeking in this way a greater political impact. A support 
group was formed with representatives from three Peruvian NGOs, namely DESCO, IDEAS and AyD, to carefully monitor the studies of these best practices and also to help in areas such as meetings with interested parties and specialized seminars on the different topics for study. An important part of this monitoring process, which contributed significantly to the project, was the fact that in nearly all of these meetings or seminars, discussions on the specific experience were combined with discussions on urban environmental management - and this helped to develop a policy and a strategy which gave coherence to the whole project.

Among the questions that constantly recurred were:

- What can we learn from our own Peruvian experiences; the best, the good and the bad practices?

- In what way can what has been learnt be fruitful in other cities of Peru? Can best practices be replicated?

Initially, the meetings were attended almost exclusively by specialists, technicians and promoters of this work. But gradually, increasing numbers of central and local government representatives attended, widening the spectrum of actors. This growing interest is seen particularly in those cities where a serious environmental problem exists. It was encouraged by the growing volume of data on the urban environmental reality which the project helped develop. For example, the mayor of La Oroya, a city in the Andes with serious environmental problems caused by the mining industry, participated in the first seminars and paid his own fare to attend them. This was also the case for the mayor of Cerro de Pasco and his team, who live in the highest mining town in the world where there are very severe environmental problems. The same holds for the district government, an NGO in Chimbote and many others.

One of the project's main strategies was to have as many meetings outside the capital as the funds available permitted. This would assure a decentralized process and a growing presence within the project of provincial institutions and people whose experiences must be included in the project's database.

This entire process of raising awareness, motivating action and disseminating findings was the main input to the first major Cities for Life Forum which took place in Lima in March 1996. Here, the results of the work to date were presented to the many institutions and people interested in the subject. We thought that, at most, 60 people would attend - but in the end, 170 participants came. This included several mayors, councillors and staff from local authorities who paid their own expenses. Once again, we learnt of the participants' enormous need for information. What stands out most is that this need almost spontaneously produced an interest in forming a permanent network of exchange, a place where we could learn from our own experience. There was an understanding that the most important kind of knowledge was not disseminated by coordinators of the Forum nor by foreign experts but by those people who had built their own experiences here in the cities. 
In the first session of the Cities for Life Forum, we worked on action plans for six different cities. Working in groups, these action plans were put together by the inhabitants of these cities, including their representatives, with support from a guide who analyzed the best practices and other interesting experiences. This participatory methodology was very different from what traditionally happens, whereby an expert leads or, in the worst cases, creates, a plan of action. Here, the participants themselves developed their plans. It was most gratifying to see the ex-mayor of Ilo helping his Cerro de Pasco counterpart in the development of an environmental action plan. As participants expressed their need to continue with this exchange of experience, we decided to create the Cities for Life Forum. Box 5 summarizes the concrete results obtained through this process.

Box 5: Key Events Before and During the Cities for Life Forum

- The national competition for the selection and investigation of five best practices.

- Two expert seminars (November 1994, May 1996) and four Round Tables (during 1997) to develop documents to synthesize the urban environmental situation and the capacity-building strategy proposal.

- The national competition to select two innovative proposals for the best cities.

- A database on best practices (29), institutions (163), documents and experts (273, of whom 35 per cent are women).

- The Bi-national Forum in which the Capacities Development Action Plan for Cities for Life was formulated, as much in the national context (for Peru and Bolivia) as for cities (March 1996).

- The international seminar in Rotterdam for exchange and analysis of the results of similar projects in India, Senegal and Holland as well as in Peru and Bolivia.

- The publication of the book "Cities for Life" edited by Liliana Miranda and presented in Istanbul at the Habitat II conference.

- Establishment of the Cities for Life Forum in the first two assemblies (August 1996 and October 1996) and its public presentation at the fifth Round Table, "Negotiating the Action Plan for Cities for Life" (November 1997).

- Seminar Trujillo-Cajamarca-San Marcos (February 1997).

- First course for environmental promoters for cities (May 1997).

- Community preparation and response; disaster prevention preparation for El Niño (January 1998). 


\section{NATIONAL CITIES FOR LIFE FORUM}

THE PRINCIPAL INSTITUTIONAL result of this process was the constitution of the Cities for Life Forum. With this effort, one can channel the investment and capacities of local authorities, institutions and experts, NGOs, grassroots organizations, public functionaries, members of the press, university members and the citizens themselves towards addressing the critical environmental problems in cities. As members of the Forum noted, the most significant achievement is "...to have involved different actors into a network whose perspective is to contribute to environmental management in Peru, incorporating NGOs, municipalities, universities and grassroots organizations - in itself an example of inter-institutional negotiation at a national level, creating awareness and authority in the theme of environmental

16. A member of the Forum in response to a questionnaire on the Forum's successes and failures. management."(16)

The Cities for Life Forum agreed to establish a small management team to lead and organize the fulfilment of its main activities. The team consists of a coordinator, a principal assessor and a technical coordinator, supported by a representative from the Institute for Housing and Urban Development Studies (IHS).

The composition of the Forum reflects the Forum's recognition that effective urban environmental management requires the leadership of local government, but a leadership committed to concertación and that invites civil society to combine efforts. Initiatives from civil society cannot substitute for the action of (local) government, and the state's agreement and support is needed. Thus, the Forum brings together local municipalities - represented by their mayors - NGOs, grassroots organizations, university teachers, experts and academics, integrated within a spirit of common goals since experience shows that sectoral or isolated actions do not lead to sustainable changes. However, we do recognize the capacity of leadership, of mobilization and of pressure from civil society (whether it be NGOs, popular organizations or public opinion in general) especially in those cases where the governmental role is at present indifferent, contrary to or even antagonistic to urban environmental management.

The Forum's main task is to disseminate and support the application of lessons learnt from the best practices analyzed in the preparatory phase. During the process, some key factors were identified. Environmental management initiatives tend to be more satisfactory when the following conditions co-exist:

- clear evidence of environmental problems;

- awareness-raising and popular motivation;

- favourable environmental policies from local governments;

- availability of some local resources;

- continuity of local leadership;

- interventions which come as a result of a consultative process.

The research findings highlighted the most important factors for success: continuity of leadership; a process of concertación 
among the actors; and a participatory process by which all actors work together to develop a shared vision of the future. Such a vision refers to the development of a long-term vision for the community, region or city in question. Within this process, efforts are made to recognize conflicts of interest and to seek consensus about the common objectives which can unite us.

The lesson learnt on the importance of developing a shared "vision of a common future" is valid also for the Forum itself. This can be seen in the substantial amount of time invested in collective exercises by all members of the Forum in developing a shared vision.

Thus, the Cities for Life Forum promotes democratic practices by citizens to unite local efforts and resources. In doing so, it outlines a new logic for urban development from the environmental perspective. This new logic must overcome the traditional focus which sees "environment" only in terms of environmental health, involving urban services such as piped water, sanitation, garbage collection and road-cleaning. To overcome this, the Forum promotes inter-institutional, multi-disciplinary and inter-sectoral consultation between public and private actors, between municipalities and between different levels of government (national, regional and local).

The Forum's strategic plan and framework were developed in two successive general assemblies and during the Fifth Round Table, "Negotiating the Cities for Life Action Plan", in November 1996. These documents are the result of a constant effort to "peruvianize" the principles, objectives, priorities, discourse and international agreements which have been noted in the Habitat Agenda and in Agenda 21. They are also based as much on lessons from experiences in Peru that have yielded successful results as on negotiation, permanent consultation and the real capacities of the different local actors in Peru. As a result of these meetings, we, the Forum members defined our vision, our mission and our main proposals - see Box 6 .

This way of working might be considered an inefficient way of investing our time but it is justified by the results that have been achieved. A collective leadership has been achieved, in itself the fruit of consensus. Constant consultation between all members means that all feel part of the Forum and consider themselves co-owners of what the Forum produces: they are the Forum. They are aware of their contribution, are aware of the fact that their information is valuable for others and they know that sharing this information enables them to obtain more.

As must now be evident, the Forum seeks to strengthen existing activities in each city before developing new activities. The introduction of Agenda 21, and within this of Local Agenda 21, gives them a new perspective on the progress of their work. The concept of Local Agenda 21 is relatively new - coming out of the UN Earth Summit in 1992. But it is a powerful instrument, both in political and technical terms, which brings coherence to many scattered interventions. None of the practices analyzed in the investigation phase took into account Local Agenda 21s. But the three integrated environmental management experiences showed many Agenda 21 characteristics. 


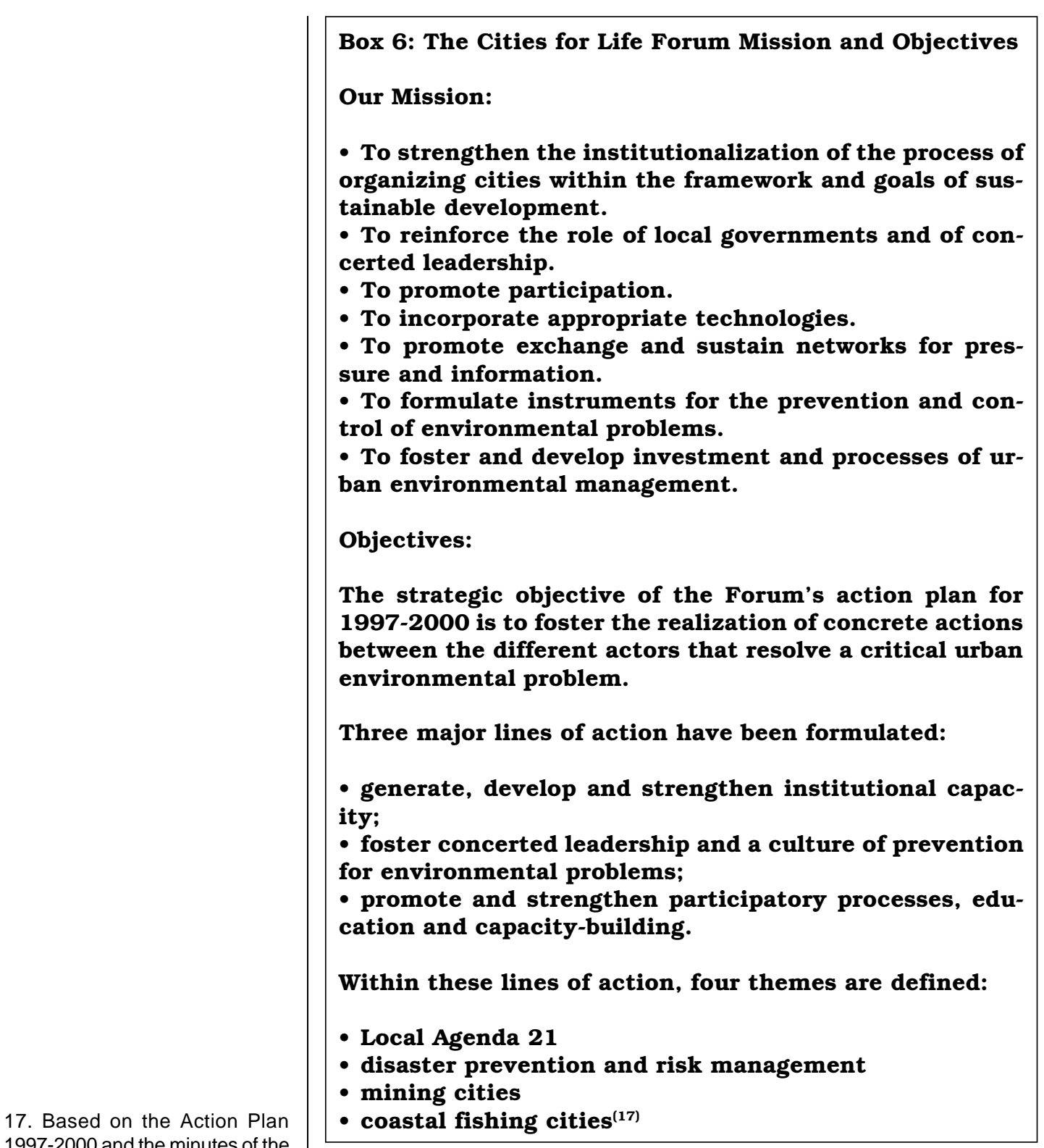
general assemblies.
The current mayor of Ilo, who was working on the environmental management plan before the Rio Summit, explained in the Forum's seminar: "After the fall of the Berlin Wall, I lost confidence in ideologies and concepts. In effect, the ground fell from underneath me. Now, within the Agenda 21 scheme, I can once again find useful guidelines for the development of my city. Amongst those people who are working in these issues, I can find again a strong agreement with ideals which make me think with gratitude of my political past as a man of the left. However, now is the time to establish for ourselves more viable and concrete goals." The mayor of La Oroya responded: "You are indeed correct, my friend. But there are also some differences. Remember how many times we went to the wives of the presidents to 
push for decentralization, to have the power to make local decisions and we always blamed others for our slow progress. Agenda 21 clearly indicates to us that we, as local government, can help ourselves. This is our responsibility, which we must take, without wishing that others do it for us." The Forum unites people who have long worked in isolation. To meet others working in the same spirit strengthens their commitment and their leadership in their own locality.

\section{ENSURING SUPPORT FOR THE ACTIONS OF ALL OUR MEMBERS}

THE NEED TO support and strengthen existing activities requires the Forum to organize as many events as possible outside Lima. The presence of the Forum in its members' cities requires a mobilization of local expectations. This can be illustrated by the third "Expert Seminar" which is the story of the participants' attempts to visit three Forum cities in three days in February 1997.

It is quite a challenge to visit three cities in three days and combine a full work programme with visiting interesting experiences in participating cities. Although all Forum members had to find the funds to come to Lima, this did not prevent them. The 64 participants, including national government officials, mayors and council members, first embarked on buses to look around Trujillo. As always, the programme was organized by the receiving city. The University had organized two guides but, within ten minutes, the mayor of Trujillo had taken the microphone and started telling the participants his story of the city, both the successes and the failures. We visited both the recovered beach areas, a new irrigation/forestation project and the settlements under serious threat of disaster. At the municipality offices, we were given an official presentation - with all the local press present - of the environmental management plan of Trujillo.

After dinner, we travelled overnight to Cajamarca where there were presentations on how to develop a Local Agenda 21 and on the current legal framework and proposals for change. Here, the network approach seems to be successful. The presenta-

18. The AMPE is the Associación de Municipalidades Peruanos (the Association of Peruvian Municipalities), which brings together all Peruvian district and provincial municipalities. AMPE organizes national congresses to define and defend the municipal interests and functions with an executive council and representatives from the ten regions of Peru. Elections for the new council and the regional representatives will be held in February 1999 after local elections in October 1998. The Forum has a covenant with the AMPE. tions were all given by Forum members and that for the Local Agenda 21 drew heavily on what had been learnt from the best practices analyzed. The introduction of the legal framework was a joint effort by various lawyers in the Forum. The issue was immediately taken up by some of the mayors present and a separate working group formed to develop the proposal into something that could be presented at the Fifth Congress of the AMPE (bringing together 500 Peruvian mayors) later that week. ${ }^{(18)}$ Other working groups were formed to cover different areas of the draft manual for developing a Local Agenda 21 and a fifth working group worked on finalizing the Forum's plan of action.

After a few hours of tough discussions, there was an abortive attempt to visit some of the experiences in Cajamarca but, in a later presentation, the participants got a clearer idea of what is 
actually going on in the city, which won the first prize in the national "Best Practices" contest.

In the third city, San Marcos (whose programme is outlined in Box 4), the participants were met by seven new mayors: the provincial mayor and six of his seven district mayors. Although political colours differ, planning is a joint effort leading to a coherent policy. One of the secrets of San Marcos's success is that the committee decides to work only on those issues they agree upon. They never wait for a final consensus on all problems to be solved but focus on concrete actions that all want to support.

The working groups met again and the action plan, the manual and the legal proposal were edited. In a final official meeting at the municipality offices, we were all named "honoured visitors of San Marcos" and received a certificate and an official municipal resolution of our presence.

Visiting member cities with the whole Forum has several objectives. It strengthens the network, especially the important personal relations between those who are experienced and those who are still at the beginning of a process. It enables Forum members to know every locality that plays a role in the training materials. But it also strengthens the group taking the lead in urban environmental management in the city. Wherever we go there are official events, press and cameras. Our presence gives recognition to the work done locally, helping to bring it to the forefront of city activity, and supports the pioneers in their difficult work.

The seminar ended in a glorious party and the following day, the conclusions regarding the proposal to improve the legal framework were disseminated at the 500 mayor AMPE Congress. The president of the AMPE - the mayor of Cajamarca and a Forum member - ensured the presentation of the proposal in one of the plenary sessions of the Congress. Many elements are included in the Congress's official conclusions and recommendations. A few days later the text was published in one of the most important national newspapers.

The Forum has put forward many initiatives to stimulate the development of Local Agenda 21s. The basic strategy of the action plan is to establish a system of annual prizes for a "City for Life", to tackle one critical aspect of its Local Agenda 21 or sustainable local development action plan. Round Table participants called this action plan the principal instrument for achieving Cities for Life in Peru. But the Forum members also pointed to the urgent need to develop the management capacity to be able to use this action plan in each locality, thus encouraging a larger number of cities to use this instrument, with or without the incentive of a prize (although with the incentive of recognition and accompaniment throughout the process). Thus, the Forum's action plan contains three major kinds of activity for which funds are currently being sought:

- annual city prize for a convincing proposal for a Local Agenda 21;

- decentralized training and capacity-building for different actors;

- consultation on and proposals for the establishment of environmental norms, standards and regulations. 
Box 7: The Strategy of the City for Life Forum

- To systematize the lessons learnt - both of good and bad practices in Peruvian urban environmental management and follow the developments through time.

- Best and good practices, contributions to events and scholarships for courses are selected in a contest with independent juries.

- Each locality requires its own approach but common features of the best practices serve as guidelines - without claiming to represent blueprints - to promote Cities for Life.

- Permanent and open concertación with all members.

- A constant update on "the state of the art" and of the areas of conflict in the field of Peruvian urban environmental management.

- Developing strategies for incremental improvement, starting with small-scale commitments and investments to stimulate larger investments and actions.

- An open and democratic call for participation, information exchange and dissemination, aiming at the participation of the most interested and most committed actors. This includes constantly calling upon those local government and national government representatives who have been supportive during the establishment of the Forum.

- Offering a constant forum for discussion of proposals, policies and investments.

The action plan as a whole is not yet funded. The work is mainly supported by voluntary work and has limited financial support from member institutions. With limited staff capacity and much goodwill, and a lot of (mostly voluntary) work by the Forum members, technical assistance has been provided to several member municipalities. Owing to a diversification of the funding sources, several municipalities have been supported in the development of their environmental development plan. ${ }^{(19)}$

The objective of decentralized training has been taken up by the Education Programme in Urban Management for Peru (PEGUP) which began in March 1998 and which will run for four years. The Forum launched this with its principal alliance, the Institute for Housing and Urban Development Studies (IHS). PEGUP concentrates training and capacity-building activities along two lines of action:

- An academic line, by creating three Masters Courses in Urban Environmental Management in the three member universities of the Forum (UNSA in Arequipa, UPAO in Trujillo and UNI in Lima); and training of trainers.

- An extra-academic line which will be developed in concertación with the newly constituted regional nucleus of the Forum, consisting of high level seminars, national fora, development of training materials for long-distance learning, radio programmes, Internet pages and courses for community leaders. 
20. Drafts of "The Cities for Life Manual on Developing a Local Agenda 21" were prepared by the former mayor of llo, Dr. Julio Díaz Palacios, one of the driving forces behind the Forum, drawing both on international documents and on all lessons learnt from the Peruvian best practices. The drafts were discussed in many Forum meetings. The document is currently being revised and publication is planned for 1999 .

21. San Agustín University, Arequipa (UNSA) and the National University of Engineering (UNI), both members of the Forum, and the Institute for Housing and Urban Development Studies (IHS) of Holland.
Several member municipalities and NGOs have already expressed the intention of sending staff to be trained and even two mayors are considering applying.

To enable the implementation of PEGUP, the Forum recently changed its organizational structure. The secretary of PEGUP was installed in the Forum's offices and three decentralized management nuclei of the Forum were formed in addition to the national nucleus: one each in the South, the North, and the Central and Amazonian regions. The decentralized management nuclei are led by the most active and enthusiastic members of the Forum in the process prior to PEGUP.

The decentralized training started on a small scale with a course for environmental promoters held at the university of Arequipa in which the concept of the manual, as discussed during the seminar in Cajamarca, was a major training tool. ${ }^{(20)}$

\section{TRAINING ENVIRONMENTAL PROMOTERS}

IN APRIL 1997, a national competition was convened with 25 grants available to help fund representatives from nine different cities to participate in a course for environmental promoters for cities. To obtain one of the grants, the applicants had to form a team in their city with at least one representative each from local government, NGOs and community organizations. Each team prepared a preliminary environmental profile. The grants were awarded according to the following criteria:

- availability and use of urban environmental information and indicators collected by the team;

- combined presentation of candidates for each city or locality;

- experience, management and commitment to the theme within their city;

- whether they are members of the Forum and whether they have participated in other Forum events;

- whether there exists any Local Agenda 21 process initiated in their city of which they are already a part.

The winning teams received three grants, encouraging them to send four or five members of their city on the course. By using the grants as seed money, 12 city teams were formed to take part in the course.

The course took place over ten days in May 1997 in Arequipa and Ilo, in association with various local, national and international institutions. ${ }^{(21)}$ As usual, participation was much higher than had been anticipated; instead of 30 participants, 62 came from 18 secondary and intermediate cities of Peru, including five mayors. Most course participants paid their own fares and accommodation costs; the only subsidy they received was to cover the registration fee.

The course's main objectives were to promote the formation of Local Agenda 21 committees in the cities and to train the participants to take the lead in the process of formulating these Local 
Agenda 21s. The course combined theory and practice and was based around four themes:

- Conceptual Theory: developing the concepts of sustainable development, urban management and environmental management of cities.

- Experiences: presenting different Peruvian and international experiences in environmental management for cities such as Tilburg, Holland (with the collaboration of the Association of Municipalities of Holland - VNG), San Marcos, Cajamarca and Ilo - and a visit to Arequipa including a Round Table discussion.

- Instruments: in which concepts and methodology are developed for

- participatory discussion in Local Agenda 21s;

- environmental profiles of cities;

- the promotion plan for Local Agenda 21s;

- the national legislative institutional framework; evaluating environmental risks (Ecorisk Project).

- Practice: with the constitution of 12 working groups, each including three or four representatives from the same city and, in some cases, from some cities whose participants had arrived individually, 12 environmental profiles were drawn up of the following cities: Cerro de Pasco, Ilo, Piura, Trujillo, Tarapoto, Chimbote, Villa El Salvador (within Lima), Arequipa, San Marcos, Tiripata, Sullana and Paita. In addition, 13 Local Agenda 21 promotion plans were developed including a Local Agenda 21 National Campaign group with members from AMPE, CONAM and the Vice-Ministry of Housing and Construction, strategic allies of the Forum.

In addition, a Manifesto of Arequipa was created, in which citizens, authorities, institutions and businesses were called together to participate actively in collaborative processes to create their Local Agenda $21 \mathrm{~s}$.

\section{SUCCESSES}

THREE FACTORS TURNED out to be key, both in the best practices analyzed and in the subsequent process of the Forum's constitution and consolidation:

- favourable political will from governors;

- large-scale, organized and permanent participation from the population and its institutions; and

- a growing knowledge, awareness and information about the urban environment.

Until the end of 1994, international agencies working in Peru did not pay much attention to the urban environment; indeed, there were no formal agendas for its protection. The process described above and the activities of the Forum have been particularly valuable in bridging this gap now that the agreements from 
the UN Habitat II Conference (especially the Habitat Agenda) have highlighted the importance of urban issues. From these lessons, better and probably different experiences from those in the past are now being promoted.

With the building of a strong network, where members share experiences, information is open and available to all. This strengthens innovative practice through recognition being accorded to those who were responsible for the innovations, and helps to reduce isolation. Today, of the 18 municipalities which are members of the Forum, 12 are working on their environmental profiles and implementing Local Agenda 21s in their cities. Most do so without needing outside help and this strong network, the Forum, is a network of learning. As Forum members often stress, each has been able to draw on each other's real experiences, especially in developing collaborative planning. This has helped them to learn how to implement urban management action without committing unnecessary errors. The Forum also provides an important professional back-up for local initiatives, since it offers not only consultancy but also a presence, whenever possible, at important events.

Several other institutions are starting similar initiatives; some have become members of the Forum - including the NGOs OACA, Calandria, and Co-operacción. More municipalities have joined, including those of Huancayo, Tarapoto, Goishco and La Banda de Shilcayo (four Peruvian cities with serious environmental problems) who were integrated into the Forum at the Third Assembly, in October 1997. The Forum has helped to introduce, promote and strengthen the environmental focus in the promotion of urban development within the principal Peruvian cities and also at a national level. As the consulted Forum members point out, "...we have managed to put into practice and into the agendas of Peruvian development institutions a new development paradigm: collaborative and participatory urban environmental management." Now, local and regional development plans need to consider the environmental dimension to become complete; in addition, local management processes need to be supported by the participation of the actors themselves, whether at the planning stage or in management itself.

The Forum has been set up in its own institutional space, recognized, respected, consulted and accepted by most of the main actors in sustainable urban development (central government, municipalities, NGOs, universities, professional colleges and, to some extent, community leaders). However, we are conscious that there is still work to be done with business and with continuing to strengthen work with grassroots community organizations.

The capacities of key local actors have been developed - with more professionals and local promoters available to support the process. So too has provision for the exchange of experiences among fellow Peruvians and also internationally with Bolivia and with other countries. Forum members can also draw on each others' knowledge and experience which, in turn, strengthens their capacity for negotiation and leadership.

The Forum has also allowed a more systematic understanding of best Peruvian practices. The recognition of "best practice" has 
22. See, for instance, a series of events organized by AMPE, " $L a$ Ciudad y sus Valles" (The City and its Valleys), OACA "Ciudades Sostenibles" (Sustainable Cities) and the Comisión Habitat " $\mathrm{La}$ Ciudad Sostenible, perspectivas futuras" (Sustainable Cities, Perspectives for the Future) between July and October 1997 in Lima; these show the interest of institutions in investigating these themes more deeply. strengthened the work in the cities who were judged to have achieved it and has allowed a permanent exchange of things learnt (including both positive and negative factors). This encourages and helps in the development of proposals, methodologies and instruments for democratic negotiation and participation in the environmental management of the city. This is recognized by Forum members, who stress that “...the most important provision of the Forum is that it provides us with simple but effective management tools. The training offered is based on existing practices in the institutions. In the same fashion, it has incorporated the theme of strategic planning, specifically in urban environmental management." In short, Forum members understand the value of developing a specific methodology for the process of planning, specifically in the environmental field.

Another important change to which the Forum has contributed is to ensure that cities' environmental problems are considered and better understood within the traditional environmental networks - and also by key institutions within national and local government including the municipality of Metropolitan Lima (whose present Director of the Institute of the Environment, the architect Arnold Millet, won the competition with the Pantanos de Villa experience), CONAM itself and a number of municipalities. This has helped ensure that the understanding of environmental problems in Peru has moved beyond an exclusively "green" focus. Industrial and urban pollution is a subject which NGOs, professionals and central and local governments are starting to discuss and act upon. ${ }^{(22)}$ As the consulted members of the Forum say, "...the construction of visions of sustainable cities, that the city for life is the goal to which we all aspire, and one that can be realized, that a balance between the environment and development is needed, and that a city that will be inherited by our children must be cared for, today more than ever - all these make up the vision that gives the Forum its power of leadership and of bringing people together."

\section{PROBLEMS ENCOUNTERED}

\section{a. Unfavourable Political Will}

AS NOTED EARLIER, one of the main problems encountered is the absence of political will at national level. The Forum lost a lot of time and opportunity in its attempts to interest and involve many central and regional government bodies. One example of the lack of interest by national government was when the ViceMinister of Housing and Construction, in spite of being president of the official Habitat II Commission, was relieved of his responsibilities by orders from above. He was removed from the official delegation in Istanbul and replaced by the manager of the Banco de Materiales, thus disassociating the activities of the unofficial Peruvian delegation from those of the official one.

There is a comparable lack of political will in some cities. For instance, in Chimbote, the mayor has made no commitment to environmental action despite the existence within his city of a 
strong and legitimate space for negotiation, incorporating 41 organizations from civil society, district municipalities and regional government. This body, the Association for the Development and Conservation of the Environment in the Province of Santa (ADECOMAPS), is fighting to save El Ferrol Bay which is seriously damaged by pollution from fishing and fishmeal production activities (see the paper on Chimbote in this issue of Environment and Urbanization for more details).

\section{b. Urban vs. Environmental Focus}

Many disagreements emerge in the numerous discussions between professionals working on urban issues and those working on environmental issues. Some of those who have long experience in working on urban issues can provide much-needed advice and technical knowledge to the Forum. But when these people do not find themselves in positions of leadership due both to the relative "newness" of the subject and to their lack of experience in terms of urban environmental issues, conflict often develops.

On the other hand, the "pure environmentalists" see themselves as those who really know the subject. They generally insist on working on the subject exclusively from a high scientific level which excludes the non-scientific majority of Forum members from the discussions. This process of exclusion can repeat itself in the work in the cities.

Addressing these problems requires careful management by the Forum staff. It also means accepting that, sometimes, the process may be slower in order to avoid and/or resolve the tensions generated.

\section{c. The Environment as a New Subject}

Another difficulty we face is the fact that the theme of environment in the management of cities is a relatively new one. There is very little information available on environmental conditions in cities. Nineteen ninety-four was the first time that surveys were used to identify experiences in urban environmental management and the very limited response from institutions was because most of those consulted did not consider their activities to be "environmental". So, in spite of the fact that they were working in water supply, garbage, and even forestation, they did not regard these activities as "environmental" but as "urban promotion" or "urban sanitation". Only after we interviewed them or visited the organization (93 institutions were visited during the first mission of the IHS) did they recognize that much of their work was "environmental". In subsequent years, this problem invariably repeated itself with a large number of organizations contacted for the first time.

\section{d. Competition as a Uniting or Dividing Factor?}

Asking cities to take part in competitions can present problems. For instance, how can one ensure a "level playing field" for all if, in reality, we know that neither cities nor the actors within 
them have the same level of knowledge and resources? Holding competitions risks rewarding the stronger and better endowed cities over those that may have the greatest need. The better placed institutions and municipalities, with better prospects of financing and with a higher capacity, are better placed to win prizes. We have sought to help the weaker institutions and municipalities with information packs and the Local Agenda 21 manual although we have not found a way of giving opportunities to those actors who cannot count on so much capacity.

The question remains - up to what point is the Forum's life and range of activities directly related to the spirit of competition for prizes or for public recognition? This question was raised by one of the AMPE assessors. The strength of the strategy can also be a source of weakness for institutionalizing the Forum. What will happen when the Forum cannot count on funds for prizes?

\section{e. Low Levels of Response, Outside of Meetings}

Another of the problems identified is the difficulty in getting high levels of participation outside the meetings. For example, the response rate to surveys sent out by post or e-mail is only about 50 per cent or less. Similarly, the response rate for comments on proposals for legislative changes not discussed in Forum events is very limited. High levels of participation and activity are only achieved at events where Forum members meet and work together to produce proposals and agreements but, even so, a group of Forum members has yet to take up a common proposal for Cities for Life. There is also the problem that some members do not work with each other outside of Forum events, even when they live in the same city (as in Trujillo and Arequipa). Forum members recognize that this is a serious management problem; they also recognize that information flows are slow from both sides. There is still no constant flow of communication allowing rapid exchange of information. Some members maintain that this is because most decisions are being taken in Lima, which exacerbates the lack of communication. They suggest that the Forum should send, on a monthly basis, bibliographic material, opportunities for empowerment and accounts of experiences in urban environmental management.

Being a member of the Forum does not in itself guarantee a change in attitude in urban environmental management and in concertación. The Forum can count on members with a great capacity for collaboration but other organizations exist whose representatives do not necessarily practise collaborative strategies and who have been absent from recent events.

\section{f. Limited Participation of Community Leaders and Business People}

The Forum has had difficulty encouraging the involvement of community leaders and business people, with some meetings lacking a community leader presence. The academic level of the environmental promoters course also appeared to be a problem since the five community leaders who took part had difficulty in understanding some of the content. 
There is also the continuing, almost complete absence of the business sector in spite of attempts to address this. (A representative from the Peruvian Chamber of Constructors was invited to the Round Table. The representative made no mention of the environment but instead expounded exclusively on proposals for the financing of housing). However, an analysis of experience has shown that the business sector (both medium and large organizations) does not play a role in managing the urbanization process. Rather, it is a source of permanent conflict due to its unchanging attitude towards transferring its environmental responsibilities to city councils.

At present, the relationship between the Forum and the business community is one of conflict and mistrust. Examples of this include the invention of all kinds of excuses to unsettle and denigrate the Forum's work - for instance an editorial in El Comercio, on the same day as the closing of the Fourth Round Table, stated that "...we must beware of the environmentalists since they are like watermelons - green on the outside, red on the inside." Although we have not developed a special strategy to relate to the business community, it is something that must be tried, although there are few successful experiences of collaborative relationships with the private sector from which to draw in developing our strategy.

\section{g. Financial Instability}

The inter-institutional relations of the Forum are not formal. This is a problem in terms of setting specific quotas for each member, signing financial contracts and instituting agreements made in the assemblies. This keeps the network weak and its future uncertain. However, it does also ensure considerable flexibility in its operations.

But there is the problem of funding and the uncertainty of when funds that the Forum needs to continue its work will arrive. Problems include changes in the executive structure of the Dutch Embassy, a lack of clarity from staff at the Peru-Canada Contravalor Fund and the silence and slowness in the confirmation of funding from United Nations agencies. This contributes towards an unstable income for the management team and the weakness of the Forum's internal organization team. This greatly limits the capacity of Forum staff to ensure that each city member receives the coordination and support they need. This has been partly resolved by the substantive support given by the PEGUP to the national management nucleus by installing its executive secretariat in the offices of the Forum. But problems remain for the decentralized nuclei as they have difficulties paying their telephone bills (a heavy burden) and have other logistical problems on which the professionals have to spend some time.

Problems also relate to the fact that international agencies traditionally gave priority to rural issues even in a country such as Peru where most of the population lives in urban areas. This is often founded on inaccurate assumptions about the countryside being systematically "exploited" by the city - assumptions that are no longer valid in Peru. But as more international agencies 
begin to work on urban issues, they usually begin by supporting action at the neighbourhood level, avoiding the local or city level and leaving aside experiences such as those of the Forum which seek to promote change on a larger scale and to exchange experiences at city level throughout the country. This tendency to support only neighbourhood level action also helps explain why we cannot find many examples of NGOs working at city level in urban environmental management. Since government authorities have also not prioritized environmental issues, the Forum finds few successful experiences from which it can learn.

\section{LESSONS}

WE PRESENT BELOW what we consider to have been the main lessons learnt from our work within the Forum:

- The exchange of experiences between cities and projects must be of similar practices which have some relevance to those who visit or get to know of them. Documenting experiences must include the "bad" as well as the "good" points. Ensuring such honesty and generosity requires trust and tolerance from those who present the experiences as well as from those who receive the information.

- Urban environmental management requires an integrated vision of the city and its surrounds. Much of the urban work of the 1980s, oriented more towards the sociological viewpoint and towards social science professionals (e.g. studies in urban social movements), concentrated work in urban promotion only in the poorest part of the city. By doing so, it obscured the need to manage the city as one entity, of managing the whole in a more complete and effective way. Environmental management of the city requires a holistic vision which does not exclude its agricultural or rural surrounds and which involves rich and poor zones. It needs to avoid competing conceptual foci (urban versus sustainable urban; Habitat II versus Agenda 21 ) but instead to construct new foci from existing facts and from our reality.

- The establishment of a strong tapestry of relationships between Forum members (representative institutions and people) and institutions that are supportive has been fostered by the relative "newness" of the subject. It has been rooted in the transparent management of information, in teaching concertación by practising it, in working with the people who want to work and in developing activities only where agreements have been reached (leaving to one side those on which agreement cannot be reached). We must recall that these types of problems have not been attended to for a long time. Also, that these strong institutional and personal relations are strengthening and expanding in each new Forum event.

- The decentralization of Forum activities is a key factor in its 


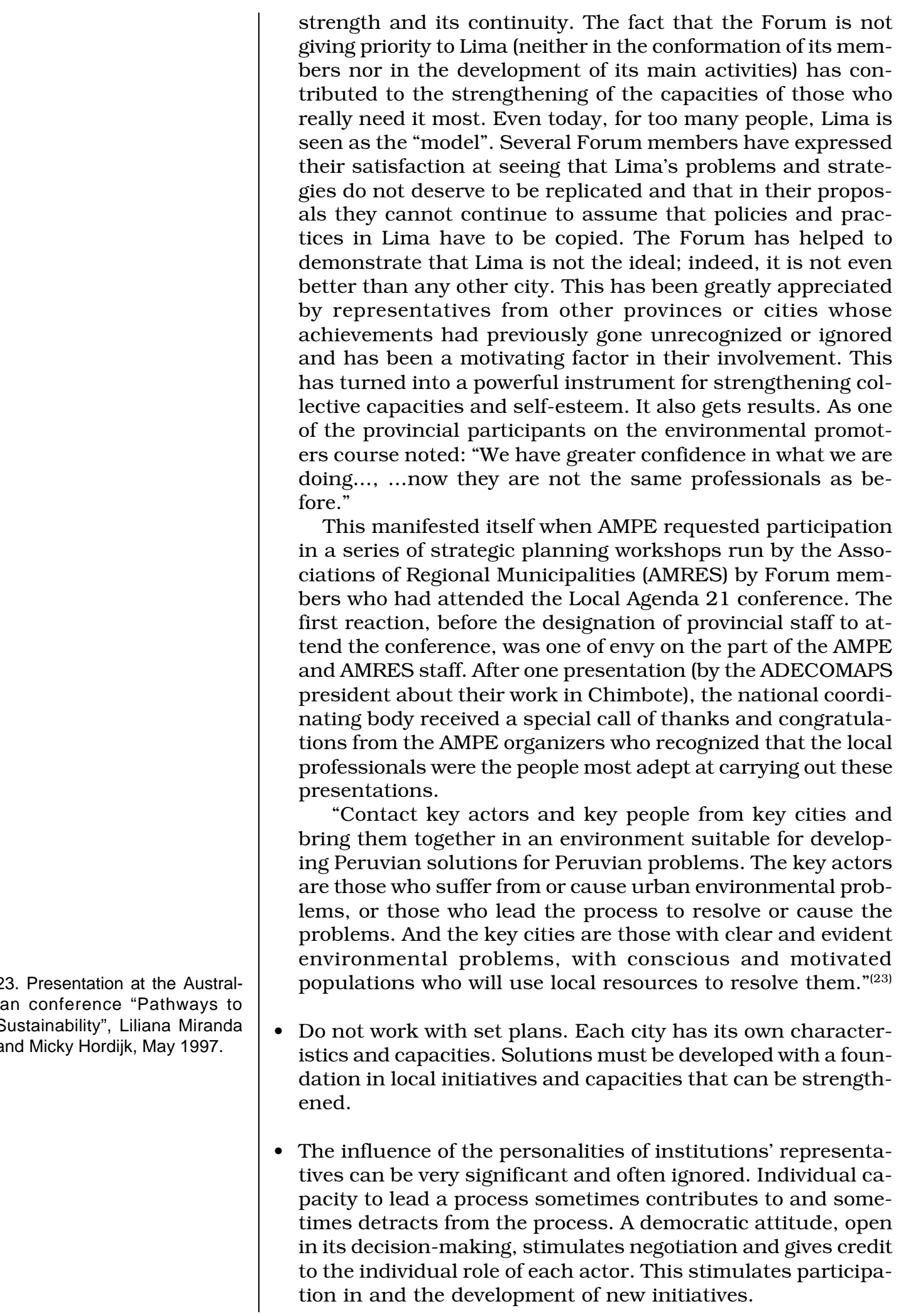

23. Presentation at the Australian conference "Pathways to Sustainability", Liliana Miranda and Micky Hordijk, May 1997. strength and its continuity. The fact that the Forum is not giving priority to Lima (neither in the conformation of its members nor in the development of its main activities) has contributed to the strengthening of the capacities of those who really need it most. Even today, for too many people, Lima is seen as the "model". Several Forum members have expressed their satisfaction at seeing that Lima's problems and strategies do not deserve to be replicated and that in their proposals they cannot continue to assume that policies and practices in Lima have to be copied. The Forum has helped to demonstrate that Lima is not the ideal; indeed, it is not even better than any other city. This has been greatly appreciated by representatives from other provinces or cities whose achievements had previously gone unrecognized or ignored and has been a motivating factor in their involvement. This has turned into a powerful instrument for strengthening collective capacities and self-esteem. It also gets results. As one of the provincial participants on the environmental promoters course noted: "We have greater confidence in what we are doing..., ...now they are not the same professionals as beore."

This manifested itself when AMPE requested participation in a series of strategic planning workshops run by the Associations of Regional Municipalities (AMRES) by Forum members who had attended the Local Agenda 21 conference. The first reaction, before the designation of provincial staff to attend the conference, was one of envy on the part of the AMPE and AMRES staff. After one presentation (by the ADECOMAPS president about their work in Chimbote), the national coordinating body received a special call of thanks and congratulations from the AMPE organizers who recognized that the local professionals were the people most adept at carrying out these presentations.

"Contact key actors and key people from key cities and bring them together in an environment suitable for developing Peruvian solutions for Peruvian problems. The key actors are those who suffer from or cause urban environmental problems, or those who lead the process to resolve or cause the problems. And the key cities are those with clear and evident environmental problems, with conscious and motivated populations who will use local resources to resolve them."(23)

- Do not work with set plans. Each city has its own characteristics and capacities. Solutions must be developed with a foundation in local initiatives and capacities that can be strengthened.

The influence of the personalities of institutions' representatives can be very significant and often ignored. Individual capacity to lead a process sometimes contributes to and sometimes detracts from the process. A democratic attitude, open in its decision-making, stimulates negotiation and gives credit tion in and the development of new initiatives. 
- The entire process depends on how much information is shared. The more information there is available to all, the higher the level of participation. Sharing as much information as possible is encouraged by receiving information. On the other hand, encouraging cities to share information amongst themselves fosters a healthy spirit of competition since each wishes to convert itself into an example for the rest of Cities for Life.

- Finally, as noted earlier, the understanding of environmental problems in Peru has moved beyond an exclusively "green" focus. Industrial and urban pollution is a subject which NGOs, professionals and central and local governments are starting to discuss and act upon.

\section{MEASURING THE FORUM'S ACHIEVEMENTS}

THE FORUM'S MOST important achievement is that the subject of urban environmental management is now better known, both by municipalities and NGOs, notwithstanding the fact that there was already a strong trend towards working on environmental issues. It is impossible to identify the precise influence of the Forum's many activities on what is planned and done in member cities; the real advances are due to local efforts. Yet, it is clear that the Forum provides an important role of promotion, support and awareness-raising. Here are a few examples.

- As described earlier, in the city of Chimbote/Nuevo Chimbote and its province, Santa, has been the formation of ADECOMAPS. This organization has 41 different public and private institutions which, together, make up a Local Agenda 21 committee. They are designing their first project, cleaning up highly polluted beaches and addressing the rapid growth of shanty towns. The beach project can now count on funding from CONAM. All this work is being developed and coordinated with the cooperation of the Forum.

- Arequipa had an environmental committee, formed independently a few years ago. At the course in Arequipa/Ilo, organized by the Forum, many members of that committee met up once again. This had not been planned but was motivated by the course and encouraged by the course coordinators. They developed an environmental profile and an action plan. After the course, the committee continued its work and the University of Arequipa set up a postgraduate course within the Centre for Urban Environmental Studies. The course coordinator in Arequipa won a public prize for her efforts to improve environmental conditions in Arequipa.

- The Cerro de Pasco working group continued with what they had planned on the course they had attended in Arequipa. Three months later, the Forum's coordinating team was invited (with their costs paid by the municipality) to attend the 
24. This technical assistance has been made possible thanks to a direct contract with the Programme for Development of Local Government, financed by USAID and executed by the Postgraduate School for Business Administration (ESAN). first "Environmental Action Plan Creation" workshop, in which working groups were set up, combining the methodology of the manual with the aims of the provincial development plan team. A course in October 1997 followed, again funded by the municipality.

- The "Water for Villa El Salvador" committee, formed during the Bi-national Forum, works independently, building and improving water management for Villa El Salvador. They keep us informed about the progress achieved.

- The Executive Environmental Council in the city of Tarapoto (CEPMA) developed their environmental management plan with help from the Forum. ${ }^{(24)}$

However, it is not easy to show that the relationships of confidence and the legitimacy that the Forum has fostered through its platform for proposals, visions and ideas really can contribute to improving the management capacities of actors striving for Cities for Life in Peru.

\section{FACTORS THAT CAN BE REPLICATED IN OTHER COUNTRIES}

A HIGH PROPORTION of urban environmental problems are basically the negative results of certain practices by city businesses, institutions and residents. The points below seek to draw on our experience to suggest key factors that can be replicated.

- Building cities in which sustainable development goals are met must be based on management systems which create a higher awareness of and give greater priority to urban environmental problems caused by different social actors - which, in turn, mobilizes their active involvement and participation at grassroots level in a new local institutional setting which integrates and does not exclude.

- An integrated system of collaborative local environmental management needs to be established in all cities. Clear leadership is a key part of this. Processes need to be established into which are built consent or modest collective agreements about critical or prioritized problems but without losing sight of future necessities. This must be done while promoting democratic citizen practices which allow efforts and resources at local, institutional and business levels to be united, outlining a new logic in urban development from the environmental viewpoint: sustainable urban development.

- Develop consultative leadership capable of influencing a positive vision of the future for its cities.

- Develop skills, values and mental models open to innovation and creativity which facilitate coordination, mutual assist- 
ance, solidarity and equal competition; in summary, collaboration in practice.

- Promote the integrated management of initiatives, especially in those NGOs which are still working in specific experiences. In doing so, aid agencies have to be encouraged to prioritize these types of integrated activities, avoiding the common practice of supporting isolated initiatives with short-term results.

- Develop technical and legislative capacities and the capacity to prepare policies that propose alternative norms which give priority to urban environmental policies (Local Agenda 21s). These must be rooted in the process through which public and municipal budgets are formulated and be linked to redistributive tax policies, standards and indicators of urban environmental quality, and methods of environmental conflict negotiation such as urban environmental fora.

- Strengthen local and national networks, empowering them in their linkages and interaction with different urban actors and prioritizing their inter-relationship with local government.

- Share and disseminate lessons of successful experiences. This should include developing manuals to encourage replication. It should also include exchange programmes and internships.

- Maintain a register of organizations, experts and experiences which will contribute to sustainable development of cities at local and national level. This allows the publication of directories which indicate who is doing what in urban environmental issues (and which are available to the public via the Internet, newspapers, etc.) and which include details of staff and contact addresses.

If we consider our experience, we should also take into account the opinions of some members which suggest that the actions of any national Forum should be even more decentralized, in such a way that grassroots leaders are those who benefit most directly from its activities. A more direct presence by Forum members is needed at local and/or regional events, particularly from specialists in specific subjects. Thematic groups could be formed within each region. There is also the suggestion that the Forum develop a new means of dissemination such as a bulletin or magazine, where its ideas, experiences and accounts of its activities can be published.

Each day, there is a greater awareness of the importance of the formal education system in the preparation of the environmental city. In light of this, some Forum members suggest that the Forum should develop a strategy to incorporate the role of schools in urban environmental management. 